\section{Parliamentary update}

The College has, for many years, liaised with government and parliament about mental health issues. It administers the All-Party Parliamentary Group on Mental Health and within the College there is a Parliamentary Liaison Sub-Committee. A remarkably wide variety of subjects relevant to psychiatrists and psychiatric practice are raised at Westminster, and now increasingly in the Scottish Parliament and Welsh Assembly. These are the major issues that have arisen recently.

\section{Mental Health Act Green Paper}

The Government published Mental Health Act 1983 - Proposals for Consultation in November last year (Department of Health, 1999). The deadline for submissions was 31 March 2000 and the College's response can be found at www.rcpsych.ac.uk/members/ memfs.htm. It is not known at time of writing whether the Government plans to bring forward legislation in the next parliamentary session.

\section{Psychotherapy Bill}

Lord Alderdice, a Fellow of the College and Speaker of the Northern Ireland Assembly, has drafted a Psychotherapy Bill. The Bill would provide for the registration of psychotherapists and include some related provision for the regulation of psychotherapy. Lord Alderdice has discussed the content of the Bill with members of the College's Psychotherapy Faculty and other psychotherapy stakeholders. The Bill would have first reading which would not involve a formal debate in the House of Lords but would be published and available on the Parliament website. In view of the time left, Lord Alderdice does not anticipate being able to take the Bill through all its stages in this parliamentary session but hopes it will act as a focal point for debate among interested groups before being reintroduced.

\section{Representation of the People Act 2000}

This Act, which deals with the registration of voters and makes provisions in relation to voting at elections, received Royal Assent on 10 March 2000. It will now be possible to register to vote from a psychiatric hospital address. Previously it was only possible to register from a home address (or a general hospital). Long-stay patients without a home outside the hospital are thus enfranchised. The Act also enables people to have their names removed from the electoral register sold to companies for direct mailing purposes. The full register will still be available for public consultation.

\section{Health Select Committee}

On 21 January 2000 the House of Commons Health Committee announced that it was to conduct an inquiry into 'the provisions of NHS mental health services'. The College submitted written evidence for the inquiry (available on the College website at www.rcpsych.ac.uk/ members/memfs.htm). The Registrar gave evidence on behalf of the College on Thursday 11 May 2000. The Committee is expected to report in the summer.

\section{Home Affairs Select Committee}

On 14 March 2000 the Committee published its report on the Government's proposals on dangerous severe personality disorder (Corbett, 2000). The Committee concluded that substantial initial investment would be needed for the future management of people with dangerous personality disorder, irrespective of what other changes are made to the law affecting them or the way the facilities are organised. The Committee believed that this expenditure would be justified. The members of the Committee visited Dutch TBS clinics in Utrecht to inform their inquiry as well as hearing evidence from interested organisations, including the College. The full report and evidence sessions can be found at www. parliament.uk/commons/selcom/ hmathome.htm and the Government is expected to publish a reply to the report within two months.

\section{Adults with Incapacity (Scotland) Bill}

This was one of the first items of legislation to be passed by the Scottish Parliament. It will protect the rights and interests of adults who lack legal capacity. The Bill was subject to detailed scrutiny by three committees of the Parliament, Justice and Home Affairs, Health and Social Services (Dr Richard Simpson MSP, MRCPsych is a member) and Equal Opportunities. The Bill aims to ensure that the adult's present and past wishes would be taken into account. Advance directives will not be considered mandatory documents but will be regarded as an expression of the person's previous views. The views of the primary carer, nearest relative and anyone else having an interest in the adult's affairs will also be considered. The Bill included a clause to enable same gender partners to be considered as the nearest relative. More information on this Bill can be found at www.scottish. parliament.uk.

\section{Welsh Assembly Health and Social Services \\ Committee}

The Health and Social Services Committee of the Welsh Assembly asked for a progress report on the revision of the All Wales Strategy for Adult Mental Health Services and the All Wales Strategy for Child and Adolescent Mental Health Services. Representatives from the advisory groups working on the revisions gave oral evidence to accompany their papers on 27 January 2000. The draft strategies are now out for general consultation. For more information on the work of the Welsh Assembly Health Committee see: www.wales.gov.uk. The Assembly Secretary for Health, Jane Hutt AM, agreed that mental health must be at the forefront of the Assembly's agenda.

\section{CS spray}

The Minister for Public Health, Yvette Cooper, announced in March that the Home Secretary had considered the report from the Committee of Toxicity in Chemicals in Food, Consumer Products and the Environment on the operational use of CS spray by police officers. The Home Secretary concluded that there were no grounds to remove CS spray from police use. The Association of Chief Police Officers accepted the Committee's findings that CS spray should only be used within the current operational guidelines. The Committee did, however, recommend follow-up studies on individuals treated for the immediate effects of CS spray. The Department of Health is providing technical advice to the Home Office as the latter develops practical ways to take forward this recommendation.

A separate parliamentary question asked if the use of CS spray on people known to be in mental distress would be suspended. The Home Office Minister, Charles Clarke, said that police officers "need some means of protection against attacks even when committed by people 
who are mentally disturbed, and the safety of CS spray to all concerned must be compared with that of the alternatives, such as physical restraint or use of batons, which themselves involve an element of risk".

\section{St John's Wort}

On 1 March 2000 the Department of Health issued a press release New Advice on St John's Wort (http://213.38.88.195/ coi/coipress.nsf) giving advice on taking St John's Wort with other medication. A debate, raised by Earl Baldwin, also took place in the House of Lords on this issue. Lord Hunt of King's Heath, Parliamentary Under-Secretary of State for Health, told the House that the Medicines Control Agency had informed him that there had been no successful licence application for St John's Wort.

\section{Vulnerable adults}

On 20 March 2000 the Health Minister, John Hutton, announced that the Government was going to take action to protect vulnerable adults. Following a consultation period, the Department of Health published guidance entitled No Secrets, which came into effect immediately. This details how agencies should work together to protect those at risk and to make sure procedures are in place to deal with incidents of abuse. The document (Department of Health, 2000) is available at www.doh.gov.uk/scg/ nosecrets.

\section{New arrangements to safeguard incapacitated people's finances in England and Wales}

Part vii of the Mental Health Act 1983 lays down arrangements for persons who cannot manage their own affairs and these have been the responsibility of the Mental Health Sector of the Public Trustee's Office. The Lord Chancellor announced that, following a quinquennial review, new arrangements will be introduced. These are detailed in Making Changes - the Future of the Public Trust Office at www. publictrust.gov.uk. The Lord Chancellor will retain ministerial responsibility and expects a better quality of service to follow. Meanwhile he welcomes comments on what is proposed. He also repeated the commitment to legislate on the policy proposals in Making Decisions (Great Britain Lord
We think these issues will be of interest to you and would welcome feedback, positive or negative, particularly as to whether the topics we select are the ones of most interest. For more information on any of the above please contact Dr Roger Freeman, Chair of the College's Parliamentary Liaison SubCommittee at: armfreeman@doctors.org.uk or Christopher Walden, Parliamentary and Policy Officer at: cwalden@rcpsych.ac.uk or tel.020 72352351 (ext. 169).

CORBETT, R. (2000) Managing Dangerous People with Severe Personality Disorder. 1st Report (Session 1999-00). London: The Stationery Office.

DEPARTMENT OF HEALTH (2000) No Secrets. Guidance on Developing and Implementing MultiAgency Policies and Procedures to Protect Vulnerable Adults from Abuse. London: Department of Health.

GREAT BRITAIN LORD CHANCELLOR'S DEPARTMENT (1999) Making Decisions: the Government's Proposals for Making Decisions on Behalf of Incapacitated Adults. London: The Stationery Office.

\section{Services for Younger People with Alzheimer's Disease and Other Dementias. A Policy Paper by the Royal College of Psychiatrists Faculty of Old Age Psychiatry}

\section{Council Report CR77.}

f5.00. 20 pp.

Younger people who suffer from dementia frequently fall through the net. This paper is welcomed within the College and strongly supported by the Alzheimer's Society.

An incremental approach is advocated with the appointment of two key players; at the commissioning level (health authority/primary care groups or their equivalent) a named person responsible for planning and a clinician to act as a focus for referrals, initially two consultant sessions. An old age psychiatrist is well placed to undertake the clinical role.

After these appointments have been made the rudiments of the local service is created. At all stages coordination and networking with people already involved with younger people with dementia is important while the composition and evolution of the new service will depend on existing local services and facilities.

As implementation is incremental an immediate start can be made. These early developments will be reviewed by the Faculty of Old Age Psychiatry and the
Alzheimer's Society in 2002 to provide data for a revised document.

\section{Proposal for a Special Interest Group in Lesbian and Gay Mental Health}

\section{Procedure for establishing \\ a special interest group}

(a) Any member wishing to establish a Special Interest Group shall write to the Registrar with relevant details.

(b) The Registrar shall forward the application to Council.

(c) If Council approves the principle of establishing such a Special Interest Group then it will direct the Registrar to place a notice in the Psychiatric Bulletin, or its equivalent, asking members of the College to write in support of such a Group and expressing willingness to participate in its activities

(d) If at least 120 members reply to this police, then Council shall formally approve the establishment of the Special Interest Group.

In accordance with this procedure, council has approved the establishment of a Special Interest Group in Lesbian and Gay Mental Health, to provide a focus for discussion and research and to serve as a source of expertise within the College in this area. It is also anticipated that the Special Interest Group would make an important contribution to public education. The principal issues with which the Special Interest Group would be concerned would include:

(a) access to mental health care;

(b) attitudes within the health service to homosexuality;

(c) the relationship between bullying and discrimination of young gay and lesbian people and suicide and deliberate self-harm;

(d) substance misuse among the gay and lesbian communities;

(e) the difficulties experienced by gay and lesbian health professionals in the work-place.

Members are invited to write in support of this Group and express willingness to participate in its activities. Interested members should write to Miss Sue Duncan at the College. So far 105 members have replied to this notice, and the Council will formally approve the establishment of this Special Interest Group if 15 more members reply.

Mike Shooter Registrar, Royal College of Psychiatrists, 17 Belgrave Square, London SW1X 8PG 